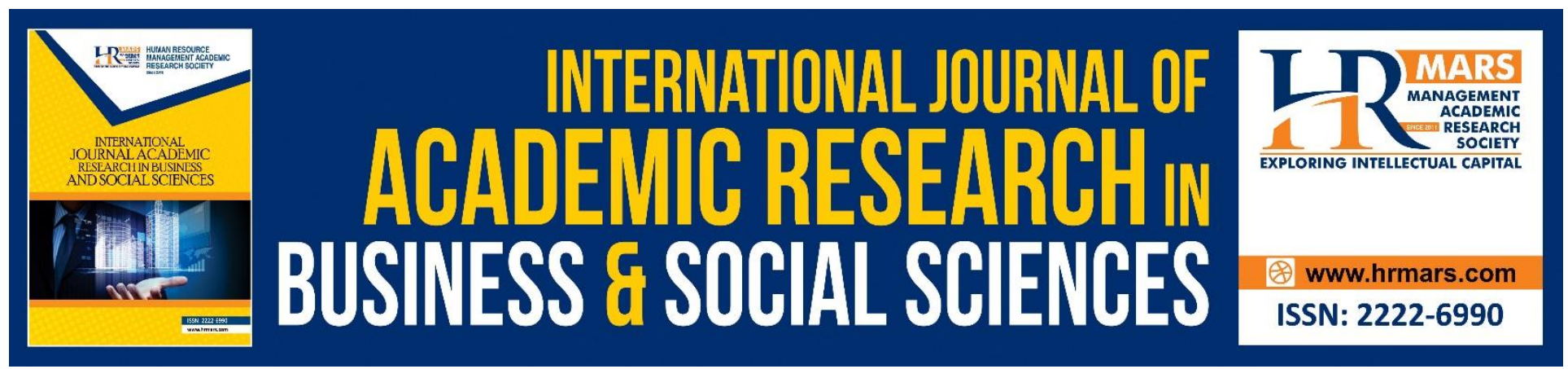

\title{
The Challenges of Technology Usage Among Coastal Fishermen in Malaysia: Review
}

Raidah Mazuki, Asnarulkhadi Abu Samah, Jusang Bolong, Khairuddin Idris

To Link this Article: http://dx.doi.org/10.6007/IJARBSS/v10-i16/8427

DOI:10.6007/IJARBSS/v10-i16/8427

Received: 24 September 2020, Revised: 22 October 2020, Accepted: 12 November 2020

Published Online: 30 November 2020

In-Text Citation: (Mazuki et al., 2020)

To Cite this Article: Mazuki, R., Samah, A. A., Bolong, J., \& Idris, K. (2020). The Challenges of Technology Usage Among Coastal Fishermen in Malaysia: Review. International Journal of Academic Research in Business and Social Sciences, 10(16), 392-400.

Copyright: (C) 2020 The Author(s)

Published by Human Resource Management Academic Research Society (www.hrmars.com)

This article is published under the Creative Commons Attribution (CC BY 4.0) license. Anyone may reproduce, distribute, translate and create derivative works of this article (for both commercial and non-commercial purposes), subject to full attribution to the original publication and authors. The full terms of this license may be seen

at: http://creativecommons.org/licences/by/4.0/legalcode

Special Issue: Youth and Community Wellbeing: Issues, Challenges and Opportunities for Empowerment V2, 2020, Pg. 392 - 400

http://hrmars.com/index.php/pages/detail/IJARBSS

JOURNAL HOMEPAGE

Full Terms \& Conditions of access and use can be found at http://hrmars.com/index.php/pages/detail/publication-ethics 


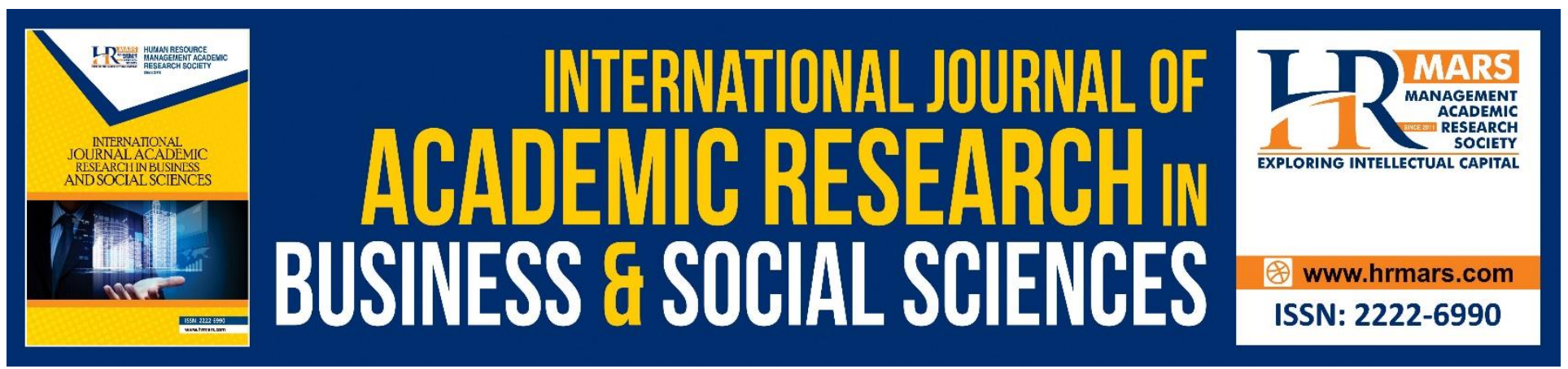

\title{
The Challenges of Technology Usage Among Coastal Fishermen in Malaysia: Review
}

\author{
Raidah Mazuki ${ }^{1}$, Asnarulkhadi Abu Samah ${ }^{1,2}$, Jusang Bolong ${ }^{3}$, \\ Khairuddin Idris ${ }^{1,4}$ \\ ${ }^{1}$ Institute for Social Science Studies, Putra Infoport, Universiti Putra Malaysia, 43400, UPM Serdang, \\ Selangor, ${ }^{2}$ Faculty of Human Ecology, Universiti Putra Malaysia, 43400, UPM Serdang, Selangor. \\ ${ }^{3}$ Faculty of Modern Language and Communication, Universiti Putra Malaysia, 43400, UPM Serdang, \\ Selangor, ${ }^{4}$ Faculty of Educational Studies, Universiti Putra Malaysia, 43400, UPM Serdang, Selangor. \\ Email: raidah0702@gmail.com \& asnarulhadi@gmail.com
}

\section{Abstract}

Fisheries industry is importance as the main source of national food security. The fisheries industry has long played a significant role in uplifting the socioeconomic status of Malaysia's rural communities. Coastal fishermen are currently undergoing a number of changes. Global development policies towards coastal fisheries shifted to focus on combating and eradicating poverty and climate change. This paper aims to address the main challenges among coastal fishermen in Malaysia poverty and climate change and makes recommendations for the future development. Information Communication Technology (ICT) play the following roles in information exchange, knowledge sharing, promotion of education, monitoring illegal fishing and price information provisioning to the coastal fishermen. There are many potential benefits offered by the advance of the fishing ICT such as GPS, mobile phone and echo sounder. It is essential to expose the advance and modern technology to the rural community especially the fisherman community. Thus, this paper will reveal several potential ICT tools for coastal fishermen to encounter the challenges.

Keywords: Challenges, Coastal Fishermen, Poverty, Climate Change, ICT, Community Development

\section{Introduction}

\section{Coastal Fisheries in Malaysia}

Fisheries industry is importance as the main source of national food security (Kittinger et al., 2013). Malaysia contains of multi-species and multi-gears fishery as a tropical country. The marine captured fisheries in Malaysia can be categorized into two types, namely coastal or inshore fisheries, and deepsea fisheries based on the areas where the resources are exploited (DOF, 2019). Continuously, the coastal fisheries have been the main attention of fishing activities. The coastal fisheries are categorized by types of fishing gear, technology and operation duration. In 2016, there was a 
INTERNATIONAL JOURNAL OF ACADEMIC RESEARCH IN BUSINESS AND SOCIAL SCIENCES

Vol. 10, No. 16, Youth and Community Wellbeing: Issues, Challenges and Opportunities for Empowerment V2. 2020, E-ISSN: 2222-6990 @) 2020 HRMARS

decreasing of $6 \%$ for licensed fishermen from the previous year. Table 1 showed that, the number decreased starting from 2015 (DOF, 2019). Parallel with this, at the same year Fisheries Development Authority of Malaysia (FDAM) reported that there was a decreasing of $44 \%$ in fish landing among coastal fishermen from 2015.

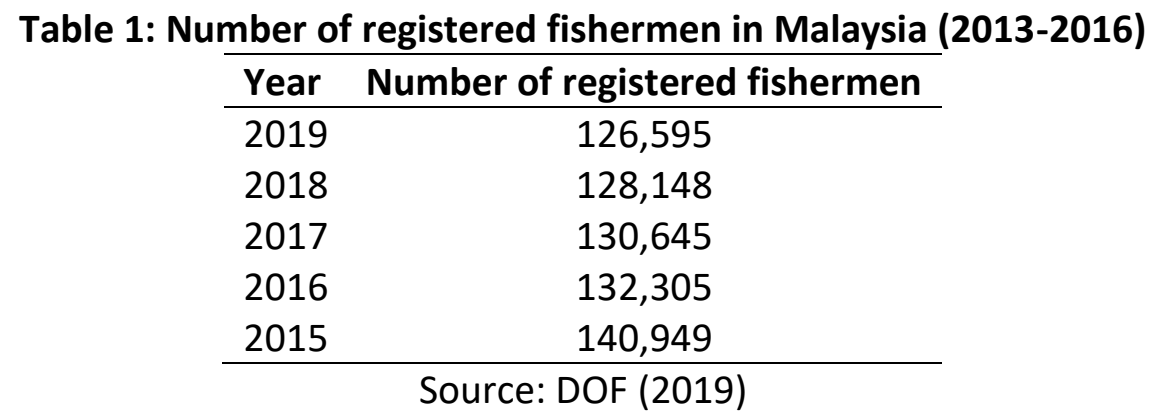

The role of the fishermen in sustaining the food supplies of this country is essential. Fisheries has been identified as a strategic sector in the government's programed to increase domestic food production and as a key element of food security and nutrition strategy livelihoods. The fisheries industry has long played an important role in elevating the socioeconomic status of Malaysia's rural communities. Majority of Malaysia's fishermen are located in rural areas. Malaysia's coastal fisheries employ more than $80 \%$ of the fish landing and provide local communities a source of protein. The government wants to improve the export potential of fisheries as part of wider efforts to increase rural employment and tackle poverty among coastal communities in addition to increasing domestic food supply. In regard, the Malaysian government has established two agencies which are Department of Fisheries (DOF) and FDAM for fishermen development.

In Malaysia, the coastal fishing activity is a full-time job. During bad weather season, coastal fishermen income may be added by non-fishing activities. For example, some of the fishermen family have an initiative to open up a small and medium enterprise (SME) - selling fish chips etc. Moreover, the coastal fishermen usually use traditional technology and borrowed capital from others (tauke, bank and other agencies). Up to half or more of the catchment is for own consumption compared to trade. The fishermen communities are commonly isolated; geographically and socially. Their income are much lower than the national poverty line - average RM 580 (Kuperan \& Abdullah, 1994; FAO, 2016; Muhammad et. al, 2016).

\section{Challenges among Coastal Fishermen in Malaysia}

Admitting the strength of fisheries industry in elevating the rural socioeconomic status and its overall importance to the food security of the country, sustaining the fisheries industry has become a priority. However, the industry is facing prominent threats such as climate change (Shaffril, Abu Samah, D'Silva, \& Uli, 2011; Muhammad et. al, 2016; Shaffril et. al, 2017) and poverty (Shaffril et al., 2011).

\section{Poverty}

Nowadays, declining of fish landing has continue contributed to the poverty of fishing communities. The poverty of Malaysia's coastal communities has reached its high rate (Alexander and Chan- 
INTERNATIONAL JOURNAL OF ACADEMIC RESEARCH IN BUSINESS AND SOCIAL SCIENCES

Vol. 10, No. 16, Youth and Community Wellbeing: Issues, Challenges and Opportunities for Empowerment V2. 2020, E-ISSN: 2222-6990 @) 2020 HRMARS

Halbrendt, 2006; Omar et. al, 2012; Solaymani \& Kari, 2014; Muhammad et. al, 2016). The challenges and barriers to poverty alleviation can be grouped as follows: environmental challenges; challenges related to governance, management and conservation of fisheries and other natural resources; challenges posed by acquiring and improving fishing technologies and operations; challenges inherent in the present use of fishery and aquatic resources such as how they are handled, processed and distributed, in the present way of marketing and utilizing fishery products, and in the present socio-economic status of fishers (FAO, 2016). The licensed fishermen in Malaysia were given subsidies such as fishing allowance - RM300 per month and fuel subsidy. Generally, subsidies are provided directly to fisherman in many forms, including grants, loans, and price or income support programs (Schrank, 2000; Clark et al., 2005). But, it is not enough to alleviate poverty among coastal fishermen in Malaysia.

Poverty among coastal fisherman is a culture. The family poverty is regarded as a fate and may not be changed. It might also because of the social strata - rural area (Bramwell, et. al., 2011). The communities have low motivation to move out from the poverty lifestyle (Willoughby-Herard, 2010). They tend to surrender to the social norms and not able to see opportunities and solutions to improve their lives (Yochum, et. al, 2011). Coastal fishermen think that it is a natural thing and they do not have to work on that. They have no intention to change their fate. Most fisherman families depend solely on fishing for their livelihood. It is interesting that they are still able to survive and do not to feel it as the limitations. They even enjoy it. Fishman (2011) suggested that the coastal fishermen should change this attitude for the future generation will not feel tired and frustrated in poverty.

\section{Climate Change}

Fishing operation among coastal fishermen relied on the consistency of the weather (Abu Samah et. al., 2012). Coastal ecosystems are considered to be extremely vulnerable to climate-change processes such as ocean warming, sea-level rise, big waves and strong wind has affected the habitats and quantity of marine life which have a direct impact upon the lives and livelihoods of coastal fishing communities (Abu Samah et al., 2012; Salagrama, 2012). As a result, it gave a significant impact on aquatic ecosystems such as fish habitat that depending on healthy coral reefs and mangroves.

Apart from that, some foreseen concerns include decreasing in productivity, species migration and localized extinctions, as well as conflict over use of scarce resources and increased risks associated with more extreme and sudden climatic change such as el-Niño and la-Nina (Mimura, 2013; Zal, 2016). Fish breeding and nursery grounds were lost, and several traditional estuarine fish species have moved away or died in the local waters. Climate change has turned into a tough challenge and high risk, as more money are required for fuel costs and crew members' salaries as fishermen were pushed to seek new fishing operation areas (Shaffril et. al, 2013). Owing to emerging threats such as climate change and declining marine resources, fishermen who used traditional methods finding it increasingly difficult to compete in the current fishing industry. In addition, traditional fishing methods resulted lower levels of productivity as compared to advanced fishing methods (AlMarshudi \& Kotagama, 2006).

The climate change does not affect the environment alone. Climate change has affected the community lifestyle as well. Coastal community will be amongst the first sectors to feel its impacts. The increasing of temperature effected the coastal fishermen health status. Studies have shown that related deaths diseases (asthma, allergic disorders, and cardiorespiratory) and illness could increase 
INTERNATIONAL JOURNAL OF ACADEMIC RESEARCH IN BUSINESS AND SOCIAL SCIENCES

Vol. 10, No. 16, Youth and Community Wellbeing: Issues, Challenges and Opportunities for Empowerment V2. 2020, E-ISSN: 2222-6990 @) 2020 HRMARS

because of climate change (Tsai and Liu, 2005). Moreover, bronchitis, skin disease, fever, flu and cough are also related with extreme temperature of climate change (Epstein, 2002).

Generally, the precise and localized impacts of climate change on fisheries are poorly understood (FAO, 2008; Stern, 2007). The direct adaptation was difficult; the focus must be on improving adaptive capacity and resilience by improving the health of fish stocks, freshwater, marine and coastal ecosystems and the communities that depend on them. Moreover, various options are available in improving the livelihoods of those coastal fishermen that at risk of the climate change effects such as adopting the ICT tools.

\section{Fishery ICT Usage among Coastal Fishermen Community}

Information and Communication Technology or ICT has a huge potential for providing appropriate knowledge and skills for the rural community. Information and communication technology (ICT) can be assumed as an umbrella under which there reside communication system, device and applications. ICT able to provide greater access to information and communication to the populations and the quality of service provided (Aker, 2010). Malaysia has taken a pro-active approach which can be seen in the 8th and 9th Malaysia plans wherein the government has taken policy initiatives and with the help of private sectors, several programmes for deploying ICT infrastructure have been introduced in remote areas such as Rural Internet Centre (Internet Desa), Community Communication Development Programme, etc.

The adoption of ICT in rural areas are among all the main agendas of the Malaysian government in order to transform its population to be more technological oriented (Zurinah, Jalaluddin, \& Mohd Asruladlyi, 2016). Rural development includes economic enhancement of people as well as better social transformation to eradicate poverty, unawareness and inequality of opportunities (Daw et. al, 2011; Mukherjee, 2011; Omar et. al, 2012). ICT usage can contribute numerous benefits through socioeconomic improvement of rural area such as rural community can market their product through WhatsApp group.

As the fisheries industry in Malaysia continues to develop, the federal government has encouraged fishermen to rely on advanced technologies to assist them in their fishing practices (MOA, 2015). In the early sixties, the most important technological development was the introduction of bottom trawl (FAO, 1982). Other than catching technology, nowadays, ICT and fishermen seem important for coastal fishermen development. The existence of ICT tools such as GPS, sonar, wireless set, computer, internet and mobile phone have certainly helped fishermen. As for example, in Pondicherry, India, weather forecasts downloaded from the US Navy's public website are broadcast by volunteers over loudspeakers to fishing villages on the Bay of Bengal for the benefit of fishermen who cannot read (Lim, 2003). Furthermore, there are abundance of previous studies that have proven ICT role in developing the socio-economic aspects of the fishermen is undeniable (Nagaraj et. al, 2018; Orue et. al., 2019; Omar et. al., 2012; Ghee Thean et al.,2012, Shaffril et al., 2017). Table 2 explained the functions and benefits that can be played by the ICT in development of fisheries industry in Malaysia. Abu Hassan et al. (2011) indicated that choice of technology is driven by numerous aspects including affordability, compatibility and the relevance of the technologies to their job. Apart from the explosion of fishery ICT development and knowledge, coastal fishermen community appear to be lacking of fishing technology. Thus, it gives a big impact on the fishermen community performance 
INTERNATIONAL JOURNAL OF ACADEMIC RESEARCH IN BUSINESS AND SOCIAL SCIENCES

Vol. 10, No. 16, Youth and Community Wellbeing: Issues, Challenges and Opportunities for Empowerment V2. 2020, E-ISSN: 2222-6990 @ 2020 HRMARS

which involve decreasing in productivity, not adaptive and responsive to climate changes (Last et. al, 2011; Shaffril et. al, 2017).

Table 2: ICT tools functions and benefits for fishermen

\begin{tabular}{ll}
\hline ICT Tools & Functions/benefits \\
\hline GPS & Marking the spots of the fish location, it can assist the fishermen to return \\
& exactly to the right place whether its daylight or dark. It will provide \\
& information such as latitude, longitude, altitude, surface speed, sunrise \\
& and sunset times, odometer and accuracy warning system.
\end{tabular}

Sonar Through sonar, fishermen can get a complete, immediately up to date, available map of the whole fishing area showing the exact location, extend, density, depth, movement, species and size of all fish shoals. In addition, information regarding sea bottom such as depth, contours, slopes and stones can easily be gained.

Echo sounder Use to measure the depth beneath the vessel or for detecting fish.

Wireless set It enhances the security aspects of the fishermen. If anything happens to them at the sea they can communicate with other vessels and the responsible agencies so that immediate action can be taken. On top of it, they can immediately share information regarding the fishing spots with the others. Moreover, through wireless set they can deal a better price with the dealer even when they are still at the sea.

Computer for record purposes (ex: profit and loss, species caught, weather condition, markets, etc.)

Internet To seek, disseminate and share fisheries related information such as market price, online applications, weather conditions, professional advices, loan services, business opportunity, etc. among/between colleague and related agencies

Mobile phone To communicate and to deal a better price with the dealer even when they are still at the sea

Source: Nagaraj et. al, (2018); Orue et. al., (2019); Omar et. al., (2012) and Ghee Thean et al. (2012). In terms of poverty alleviation which is strongly interrelated to rural development, the ICTs can be indigenized to meet local needs with content that is demand-driven and language which is intelligible to its users. Abundances of the ICTs content is in English and the information requires a higher understanding of ICTs that is dependent on high education and literacy levels. In fact, most of the coastal fishermen only possessed primary education and low illiteracy (Salagrama, 2006; Sarkar, 2012; Hamzah et. al, 2015). Furthermore, the costs associated with ICTs set-up and maintenance are also high, making questions of sustainability an issue given that is it affordable for the coastal fishermen. As a result, only fewer fishermen invest in fishery ICT resources.

The main difference here between the haves and have-nots is that the relative value of time compared to access cost is more in developed societies while the value of time in the developing societies is much less compared to access costs. Regardless of the benefits offered and persistent 
INTERNATIONAL JOURNAL OF ACADEMIC RESEARCH IN BUSINESS AND SOCIAL SCIENCES

Vol. 10, No. 16, Youth and Community Wellbeing: Issues, Challenges and Opportunities for Empowerment V2. 2020, E-ISSN: 2222-6990 @) 2020 HRMARS

efforts by concerned parties to encourage ICT usage among coastal fishermen, apparently, only several of coastal fishermen have substantially used ICT in their fishing operation.

\section{Conclusion and Recommendation}

In response to poverty and climate change challenges, at a practical level, ICT needs to be developed, adapted and implemented to reduce wastage and increase the value added to catches to balance the impact of decreasing catches on food security and livelihoods. Communities themselves must be supported through provision of services such as insurance and weather warnings to reduce risk, support for participatory natural resource management and sustainable fishing operations. Adaptation to the fisheries sector need not be restricted to alter catch size and effort. Moreover, changes in technology fishing methods will require changes to the equipment used; support may be needed to ensure that appropriate fishery ICT can be procured, including provision of credit, and to provide training and extension to broaden the fishers' knowledge of fishing techniques.

Apart from that, more research is needed into how to combat the poverty and awareness of impacts of climate change at the levels of individual and local fisheries and coastal fishermen communities. Investment is needed in the development of policies that will help reduce vulnerabilities and encourage people to take the actions needed to adapt to change circumstances. People also need to be empowered to take those actions through increased access to appropriate financial services and opportunities for training.

At the policy level, there is a need to increase cross-boundary cooperation and flexibility of regional fishing agreements to cope with shifting stocks, as well as integration of fisheries and aquaculture into other national policies on climate change, food security, water management, poverty reduction, coastal zone management etc. to reduce conflicts over resource use and ensure coherence of adaptation activities. Greater co-management and decentralization of management to fishing communities themselves will help to increase flexibility in implementation of policies, together with a greater sense of ownership and improved compliance, making management more effective and reducing costs. Management of coastal fisheries need to focus on maintaining the integrity of ecosystems, taking into account complex linkages and relationships between species and their wider ecosystems. This will require going beyond simply controlling catch levels of commercial important species.

In a nutshell, Malaysia has made significant developments in increasing the ICT information and knowledge in all rural areas. Efforts were intensified in the provision of access, particularly of the rural population, to the necessary infrastructure and info structure. This will enable all coastal fishermen to take advantage of advances in ICT to improve efficiency and productivity, thus contributing to the increased overall competitiveness of the economy.

\section{References}

Abu Hassan, M., Shaffril, H. A. M., D’Silva, J. L., Omar, S. Z., \& Bolong, J. (2011). Fishermen and ICT: Towards creating knowledgeable fishermen in Malaysia. Australian Journal of Basic and Applied Sciences, 5, 457-469.

Abu Samah, B., Shaffril, H. A. M., D’Silva, J. L., \& Uli, J. (2012). The negative environmental changes on the sea and its impact on the aspects of economic, social and health of the fishermen living in the East Coast Zone of Peninsular Malaysia. American Journal of Environmental Sciences, 7(6), 
INTERNATIONAL JOURNAL OF ACADEMIC RESEARCH IN BUSINESS AND SOCIAL SCIENCES

Vol. 10, No. 16, Youth and Community Wellbeing: Issues, Challenges and Opportunities for Empowerment V2. 2020, E-ISSN: 2222-6990 @ 2020 HRMARS 534-541.

Aker, J. C. (2010). Dial "A" for agriculture: using information and communication technologies for agricultural extension in developing countries. Tuft University, Economics Department and Fletcher School, Medford MA02155, 37.

Al-Marshudi, A. S., \& Kotagama, H. (2006). Socio-economic structure and performance of fishermen who use traditional methods in the Sultanate of Oman. Marine Resource Economics, 21, 221230.

Alexander, B., Chan-Halbrendt, C., \& Salim, W. (2006). Sustainable livelihood considerations for disaster risk management: implications for implementation of the government of Indonesia tsunami recovery plan. Disaster Prevention and Management: An International Journal, 15(1), 31-50.

Bramwell, G., Reilly, R. C., Lilly, F. R., Kronish, N., \& Chennabathni, R. (2011). Creative teachers. Roeper Review, 33(4), 228-238.

Clark, C. W., Munro, G. R., \& Sumaila, U. R. (2005). Subsidies, buybacks, and sustainable fisheries. Journal of Environmental Economics and Management, 50(1), 47-58.

Daw, T., Brown, K., Rosendo, S., \& Pomeroy, R. (2011). Applying the ecosystem services concept to poverty alleviation: the need to disaggregate human well-being. Environmental Conservation, 38(4), 370-379.

Epstein, P. R. (2002). Climate change and infectious disease: stormy weather ahead? Epidemiology, 13(4), 373-375.

FAO. (2016) Climate change implications for fisheries and aquaculture. In: The State of Fisheries and Aquaculture 2008. FAO, Rome, Italy, pp. 87-91.

Fishman, D. B. (2011). Case study research in counselling and psychotherapy. British Journal of Guidance \& Counselling. 39 (5), 510-512.

Kuperan, K., \& Abdullah, N. M. R. (1994). Small-scale coastal fisheries and comanagement. Marine Policy, 18(4), 306-313. https://doi.org/10.1016/0308-597X(94)90045-0.

Lembaga Kemajuan Ikan Malaysia. Laporan Tahunan. (2016). http://www.Ikim.gov.my/laporantahunan/. Retrieved on $1^{\text {st }}$ May 2018.

Lim, S. Y. (2003). ICT and Governance: Tana Otsustan Mina (Today, I'm Deciding) in Understanding ICT4D Thematics in Malaysia: A Sourcebook. United Nations Development Programme (UNDP).

Mimura, N. (2013). Sea-level rise caused by climate change and its implications for society. Proceedings of the Japan Academy. Series B, Physical and Biological Sciences, 89(7), 281-301. https://doi.org/10.2183/PJAB.89.281

Mukherjee, S. (2011). Application of ICT in Rural Development: Opportunities and Challenges. Global Media Journal, 2(2), 1-8.

Muhammad, M., Idris, K., Ariffin, E. H., Shaffril, H. A. M., Samah, B. A., \& Suandi, T. (2016). The impact of climate change on small-scale fishermen in Malaysia. Social Sciences (Pakistan), 11(13), 3352-3356. https://doi.org/10.3923/sscience.2016.3352.3356.

Nagaraj, B. R. S., Arunkumar, R., \& Pradeepraj, M. S. (2018). Smart real time rescue system for fishermen. Pak. J. Biotechnol, 15, 73-75.

Orue, B., Lopez, J., Moreno, G., Santiago, J., Boyra, G., Uranga, J., \& Murua, H. (2019). From fisheries to scientific data: A protocol to process information from fishers' echo-sounder buoys. Fisheries Research, 215, 38-43. 
INTERNATIONAL JOURNAL OF ACADEMIC RESEARCH IN BUSINESS AND SOCIAL SCIENCES

Vol. 10, No. 16, Youth and Community Wellbeing: Issues, Challenges and Opportunities for Empowerment V2. 2020, E-ISSN: 2222-6990 @ 2020 HRMARS

Sarkar, P. (2012). Verifying the statement of Gordon Scott 1954,- the Fishermen remains poor, in the context of coastal fishery in India '. International Journal of Scientific \& Engineering Research, 3(12), 1-10.

Salagrama, V. (2012). Climate change and fisheries: perspectives from small-scale fishing communities in India on measures to protect life and livelihood. International Collective in Support of Fishworkers.

Schrank, W. E., \& Keithly, J. W. R. (1999). The concept of subsidies. Marine Resource Economics, 14(2), 151-164.

Stern, N. (2007). The economics of climate changethe stern review (No. 363.73874 S8).

Shaffril, H. A. M., Samah, B. A., \& D'Silva, J. L. (2013). The process of social adaptation towards climate change among Malaysian fishermen. International Journal of Climate Change Strategies and Management. 5 (1), 38-5.

Shaffril, H. A. M., Samah, A. A., \& D'Silva, J. L. (2017). Climate change: Social adaptation strategies for fishermen. Marine Policy, 81, 256-261.

Solaymani, S., \& Kari, F. (2014). Poverty evaluation in the Malaysian Fishery Community. Ocean and Coastal Management, 95, 165-175. https://doi.org/10.1016/j.ocecoaman.2014.04.017.

Tsai, H. T., \& Liu, T. M. (2005). Effects of global climate change on disease epidemics and social instability around the world. Hum Secur Climate Change, 2005, 21-23.

Willoughby-Herard, T. (2010) 'I'll Give You Something to Cry About': The Intraracial Violence of Uplift Feminism in the Carnegie Poor White Study Volume, The Mother and Daughter of the Poor Family. South African Review of Sociology. 41 (1), 78-104.

Yochum, N., Starr, R. M., \& Wendt, D. E. (2011). Utilizing fishermen knowledge and expertise: keys to success for collaborative fisheries research. Fisheries, 36(12), 593-605.

Zal, W. A. (2016). Fragility and capacity building of social capital of Malaysian fishermen. Ocean \& Coastal Management, 119, 177-183.

Zurinah, T., Jalaluddin, A. M., \& Asruladlyi, M. I. (2016). Developing Smart Ict in Rural Communities in Malaysia Through the Establishment of Telecenters. Journal of Social Sciences and Humanities, 11(1), 227-242. Retrieved from http://ejournal.ukm.my/ebangi/article/view/14453/4402. 